UDC 331.21:[303.436+303.62]:331.522(477)

JEL Classification: C81, J23, J63

Doi: 10.31767/su.2(93)2021.02.10

L. H. Tkachenko,

PhD in Economics, Senior Scientific Employee, Leading Researcher,

Ptoukha Institute for Demography and Social Studies

of the National Academy of Sciences of Ukraine,

E-mail: lidiia1tkachenko@gmail.com

ORCID https://orcid.org/0000-0002-6352-6398

\title{
Information Support for the Statistical Assessment of Labor Market Demand in Ukraine
}

The statistical assessment of labor market demand has to focus on qualitative rather than quantitative characteristics of jobs from the perspective of opportunities for choice and development of employed. Such assessment of jobs requires information and technical support. A review of the available information sources on the number and structure of jobs lays the ground for constructing a comprehensive assessment methodology on the basis of official statistical observations supplemented by administrative data on vacancies. It is shown that each source has its strong and weak sides. The strong sides of official sources are systemic professional approach and standardized techniques for data collection and processing, regularity, data quality control and accountability. But these sources still remain hardly accessible for research purposes, their data are compiled by the formal and sectoral approach and published in highly aggregated form. Alternative sources, including independent analytical and marketing studies, online databases of vacancies, are displayed in open access and contain detailed vacancy descriptions. But these data are unstructured, fragmented and need careful treatment due to a high probability of the system bias caused by broad applications of marketing strategies.

The comprehensive assessment of labor market demand should be based on the results of Labor Force Survey, which enable for simultaneous structuring of indicators by social-demographic characteristics of respondents and organizational-economic characteristics of production units. Data from this survey have to be supplemented by data from enterprise surveys on labor statistics, labor conditions and business tendencies, anonymous data from the registers of the Pension Fund of Ukraine, and by data on vacancies available in the databases of the State Employment Service and private recruitment companies.

Key words: labor market, labor market demand and supply, labor force, vacancies, statistical observations, administrative data, monitoring.

Introduction. Information support for the statistical assessment of labor market demand has been developed to a lesser extent than the assessment of the reverse side of the labor market conjuncture, i. e. labor market supply. The methodology for Labor Force Survey is subject to careful design at the highest international level, enabling its implementation across the world by use of international techniques and standards. But the statistical assessment of number and structure of jobs does not have a similar all-purpose comprehensive information source, with labor market studies focused to a larger extent on supply than demand. This dissymmetry can be attributed to the human centrism imperative in social sciences.

A central postulate of the economic theory that the actual wealth of a country is its people is fully revealed in the human development concept defining the true development goal as not only growth in

(C) L. H. Tkachenko, 2021 incomes, but also as maximization of human choices by enhancing human rights, freedoms, capabilities and opportunities [1]. In view of this labor market studies put the greatest emphasis on issues of labor supply, employment, unemployment factors, working hours, work conditions and compensation etc., i. e. the indicators measuring the criteria of decent work and quality of employment [2;3]. The scopes and structural characteristics of jobs are more often analyzed in the context of macroeconomic environments or barriers that can limit employment $[4 ; 5 ; 6]$.

Methods and sources. The approach based on human centrism has never denied the usefulness or independent value of the statistical assessment of labor market demand, but highlighted the significance of such studies. This methodological approach enables to assess the number and characteristics of jobs not only from the perspective of commonplace interpretations of balance/imbalance between demand and supply 
on the labor market or meeting utilitarian needs of employers and managers, but from the perspective of wider choice, i. e. the extent to which individuals are free in their conscious choice of a suitable job and the extent to which this choice not only helps them realize their labor rights, but opens up opportunities for development. The human centrism based approach to the assessment of labor market demand offers a strong methodical ground enabling to avoid contradictions arising with prioritization of labor market supply over labor market demand or vice versa, as they become equal and interrelated.
The chosen approach sets additional requirements to information sources. There exist many sources and tools characterizing selected features of jobs, but these data cannot be mechanically compiled. Apart from analyses of their technical compliance, soundness and reliability, it needs to be confirmed that they are applicable for the assessment of opportunities involved in the choice of jobs.

Results and discussion. The sources of data on the number and structure of jobs, available in Ukraine, need to be divided, after all, into official and alternative ones (Figure 1, author's development).

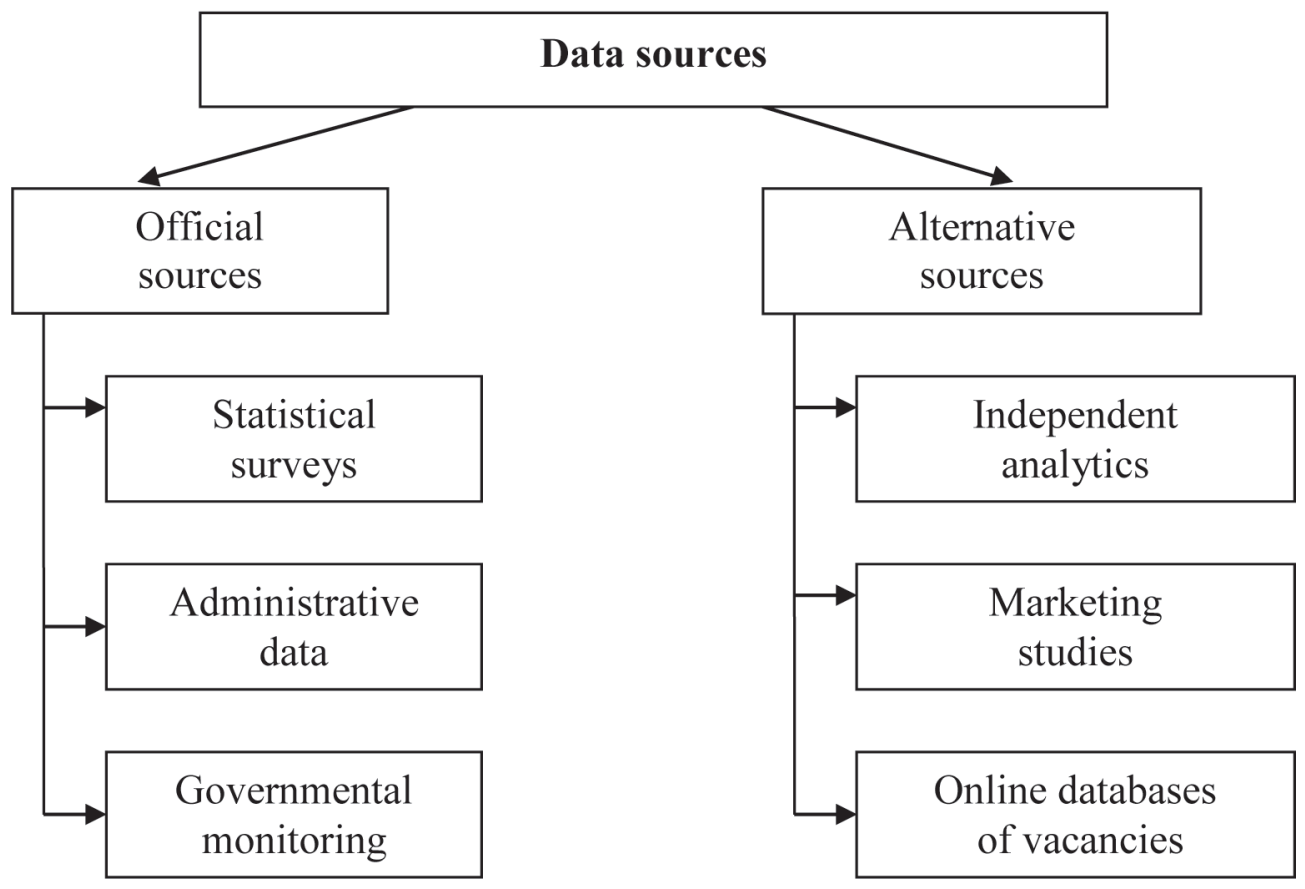

Figure 1. Sources of data on the number and structure of jobs in Ukraine

Official sources refer to data of government bodies, first and foremost official statistical data, as well as administrative data and governmental monitorings. This group of sources have notable advantages: the systemic professional approach and standardized techniques for data collection and processing, regularity, comprehensive coverage in terms of territory and statistical units, data quality control and accountability, feedback etc. But official sources have limitations, especially in accessibility and applicability for research purposes: aggregation and rigid structuring of statistical data do not enable for study of important details and links; administrative data are designed to demonstrate the scopes of administrative effort rather than the results of the process; governmental monitorings are based on formal administrative approach or ranking technique rather than on assessment.

Alternative sources, contrary to official ones, are less rigid in thematic or technical terms. Independent analytical or marketing studies address specific issues in far more explorative manner. Non-governmental organizations operating by grant funds usually publish their research results in open access. Online databases of vacancies provide detailed vacancy descriptions. But alternative sources can have drawbacks arising from their advantages: unstructured and fragmented data; data requiring too careful treatment, because the wide-scale use of marketing techniques can lead to system biases.

The detailed composition of the above sources and their applicability for the assessment of labor market demand in terms of the number and structure of jobs are discussed below.

Official statistical observations. The nomenclature of statistical observations, indicators and structural dimensions that provide information on labor market demand are given in Table 1 (developed by the author by data from [7]). 
Table 1

Official statistical observations and indicators providing information on number and structure of jobs

\begin{tabular}{|c|c|}
\hline Source & Indicators and structural characteristics \\
\hline 1.1. Labor force survey & $\begin{array}{l}\text { - Number of population by labor market status: labor force, employed persons, } \\
\text { unemployed persons, persons outside the labor force. } \\
\text { - Structure of labor force, employed persons, unemployed persons and inactive } \\
\text { persons by social and demographic characteristics: gender, age, family status, type of } \\
\text { locality and region of residence, citizenship, education level, professional education and } \\
\text { training, status in employment, membership in trade unions etc. } \\
\text { - Characteristics of the main job: type of documenting of labor relations or self- } \\
\text { employment, coverage by social insurance, eligibility for paid vacations and compensation } \\
\text { for sick leave, size of enterprise, distance of job place from residential place, type of job, } \\
\text { economic activity of enterprise, profession/occupation, working hours, wage size. } \\
\text { - Existence of additional job and its characteristics. } \\
\text { - Characteristics of unemployed persons: activity and ways of job search, causes } \\
\text { and duration of being out of employment, duration of unemployment, registration in } \\
\text { state employment service, characteristics of the last job place. } \\
\text { - Characteristics of persons outside the labor force: causes and duration of } \\
\text { being out of employment, causes of abstaining from job search or unwillingness to start } \\
\text { working, characteristics of the last job place }\end{array}$ \\
\hline $\begin{array}{l}\text { 1.2. Enterprise Survey } \\
\text { on Labor Statistics }\end{array}$ & $\begin{array}{l}\text { - Number of staff personnel in enterprises, by region, economic activity, } \\
\text { organizational and legal forms and source of financing. } \\
-\quad \text { Number of admitted and dismissed staff personnel, including by cause of } \\
\text { dismissal (staff turnover or staff reduction), by region and economic activity. } \\
-\quad \text { Number of staff personnel that were in forced underemployment (unpaid leave } \\
\text { or part-time work day/week), by region and economic activity }\end{array}$ \\
\hline $\begin{array}{l}\text { 1.3. Enterprise Survey } \\
\text { on Labor Conditions }\end{array}$ & $\begin{array}{l}\text { - } \quad \text { Number of staff personnel on jobs with harmful work conditions, by region, } \\
\text { economic activity and harmful work factors. } \\
-\quad \text { Privileges and compensations for work with harmful work conditions, by region, } \\
\text { economic activity and type of privilege/compensation }\end{array}$ \\
\hline $\begin{array}{l}\text { 1.4. Business tendency } \\
\text { survey }\end{array}$ & $\begin{array}{l}\text { - } \quad \text { Share of enterprises expecting increase or reduction in employees. } \\
\text { - } \quad \text { Share of enterprises with shortage of workforce }\end{array}$ \\
\hline
\end{tabular}

1.1. Labor Force Survey (LFS) provides information mainly in terms of labor force supply, but its results can be also used for assessment of labor market demand. The number of employed persons is not necessarily equal to the number of occupied jobs, because there are such forms of employment as sharing of job place between employees and sharing of employees between production units. But the occupied jobs obviously made the absolute majority and much better reflect the overall scales and characteristics of labor market demand than the data on vacancies. For example, the structure of employment by economic activity can give a rather full description of the structure of demand by economic sector. Data on continued training and social protection are critically important for analyses of opportunities for professional development on a job place.

Also, LFS provides information on the scales and structural characteristics of unemployment and labor force reserves that can be engaged in the labor market in certain situations. Information on attempts of job search can give an idea of the main modes of interactions between open demand and supply on the labor market. As regard the unemployed or inactive persons that have employment before, LFS provides the main characteristics of the last job. It is obvious that the economic activity of a production unit in the next job may or may not correspond with the previous one, if even the profession is unchanged. However, job changes are to a large extent inertial, especially given the lack of structural reform in the economy and poorly developed system of adult education. Hence, it can be logically assumed that in the most part of cases the next job will be linked to the same economic sector as the previous one. This assumption is less probable in case of young job seekers, especially when they are at the phase of changing temporary part-time jobs combined with professional education for a stable employment by the obtained diploma [8]. Uncertainties also occur in case of the unemployed persons lacking experiences of previous jobs and seeking the first job (this category of unemployed accounts for nearly $15 \%$ in the total unemployment). Hence, the distribution of labor force by economic activity enables to have a quite full picture of the configuration of jobs by economic sector.

The largest economic sectors in Ukraine, which altogether accounted for more than the half of the total jobs in the latest decade, were the following three: (i) wholesale and retail trade, repair of motor vehicles and motorcycles (more than $22 \%$ of the total labor force); (ii) agriculture, forestry and fishery (nearly 18\%); (iii) manufacturing (nearly 15\%). The least share of jobs was found in economic activities classified in the service sector: accommodation and food service activities; administrative and support service activities; information and telecommunications; real estate activities; financial and insurance activities; arts, sports, entertainment and recreation (less than $2 \%$ of the labor force in each) [9]. The small scale of these activities can 
be partially explained by underdeveloped infrastructures and markets specific to these services, but their overall capacity to absorb labor force is nevertheless very limited.

Results of LFS are available not only as official publications, but also in form of files of anonymous microdata, which broaden the opportunities of cross analyses for finding out relationships between various characteristics. But microdata files still have too limited content. Apart from social and demographic characteristics of respondents (gender, age, region and type of residential locality, family status, education, labor market status, status in employment), the list of variables includes only few characteristics than can be interpreted as features of jobs: occupation (aggregated by 9 groups), type of employment (formal - informal) and work hours for employed persons, causes and duration of unemployment, and ways of job search for unemployed, and causes of inactivity for persons outside the labor force [10]. Presented in this way, microdata can hardly add something useful to regular official publications of survey results. But the possibility to structure the indicators by social-demographic characteristics of respondents and organizational-economic characteristics of production units constitutes a great advantage of the data obtained from this source.

1.2. Enterprise Survey on Labor Statistics contains some modules not found in LFS, but they address only part of the employed population, namely the staff personnel of the enterprises with 10 or more employees. Apart from the incomplete coverage, the limitation of this source is caused by the impossibility of cross analyses, as the data are available only by economic activity and region. The most relevant indicators for the assessment of job characteristics are ones of admission and dismissal of employees, with the admission/dismissal ratio and the turnover of employees providing a good picture of not only stability/instability of the employment, but also the attractiveness and effectiveness of jobs.

An analysis of data from Enterprise Survey on Labor Statistics shows the stable excess of dismissals over admissions, resulting in the continuing reduction of staff personnel in enterprises. The average annual turnover (the sum of admissions and dismissals) covers more the half of the total staff personnel. In some activities, such as agriculture, forestry and fishery, construction, wholesale and retail trade, repair of motor vehicles and motorcycles, accommodation and food service activities, administrative and support service activities, the annual turnover reach or even exceeds $100 \%$ [11]. It means that enterprises dismiss and recruit personnel on almost all the jobs; recruited ones may be the same persons that worked in this job before. Although 85 to $95 \%$ dismissals are formally related with staff turnover (more often as voluntary dismissals or dismissals by employee-employer agreement), there is evidence that for employers it is a solution of the seasonal recession problem [12]. The only economic activity with a notable share of staff dismissal caused by staff reduction is public administration (more than $10 \%$ of the total dismissals). But staff reduction in this case is more often associated with reforms of administrative bodies or can be used as a way to refresh the staff.

Hence, the scales of instability in employment and jobs are impressing even in the sectors with protected and officially documented labor relations. These figures of turnover are not indicative of the mobility, because movements on the labor market are more often mechanical, with no implications for improvements of labor conditions or carrier promotion. It is clear evidence of low quality of the jobs, and there is no point in holding on to them.

1.3. Enterprise Survey on Labor Conditions addresses the employment on jobs with harmful factors at work. The occurrence of such factors is determined by the results of a validation involving sanitary-hygienic examination of the factors related with the work environment and work process and their recording. This information is important e. g. in analyses of the causes preventing from reduction of jobs with harmful factors at work and the causes making these jobs attractive for employers and employees. The main drawback of this source is incomplete coverage by factors provoking adverse work conditions (e. g. by excluding night work, irregular working hours and many other circumstances) and by economic sectors (data collect only for selected economic activities, almost without the service sector). This can be largely explained by linking the survey methodology to the outdated procedure for assessment of individual workplaces, which is often confined to formalities.

1.4. Business Tendency Survey is conducted by way of sample interview of business managers on the current performance and expected results in the next three months. These responses may or may not reflect the real situation or specific actions, being rather emotional reactions on certain moments/periods.

As regards the assessment of labor market demand, information on shortage of labor force as a factor hindering business expansion and expected change in employment (up, down or no change) is important. The limitation of this source is related with fixation of only a tendency but not a quantitative level: it remains unknown how many employees and what employees are demanded or what is the scale of expected change. Also, the survey results are very sensitive to external force majeure such as political instability or pandemic. For example, in 2020, due to quarantine limitations, business managers preferred to give very conservative estimates of their business prospects and much less frequently reported a shortage of labor force as a factor hindering business expansion [13].

Administrative data. A nomenclature of administrative sources, indicators and resources providing information on labor market demand is given in Table 2 (developed by the author using data from websites $[14 ; 15 ; 16])$. 
Administrative sources, indicators and resources providing information on number and structure of jobs

\begin{tabular}{|c|c|}
\hline Source & Indicators/resources \\
\hline $\begin{array}{l}\text { 2.1. State } \\
\text { Employment } \\
\text { Service }\end{array}$ & $\begin{array}{ll}\text { - } & \text { Number and structure of registered vacancies } \\
\text { - } & \text { Activity indicators of the State Employment Service } \\
\text { - } & \text { Number and structure of persons hired by private intermediaries } \\
\text { - } & \text { Database of vacancies }\end{array}$ \\
\hline $\begin{array}{l}\text { 2.2. Pension Fund } \\
\text { of Ukraine }\end{array}$ & $\begin{array}{l}\text { - Number and structure of insured persons for whom the single social contribution is } \\
\text { paid } \\
-\quad \text { Register of insured persons } \\
-\quad \text { Service "Electronic Employment Record Book" }\end{array}$ \\
\hline $\begin{array}{l}\text { 2.3. National } \\
\text { Agency on Public } \\
\text { Service }\end{array}$ & $\begin{array}{ll}\text { - } & \text { Number and structure of public officials } \\
- & \text { Number and structure of vacancies in the public service } \\
- & \text { Database of open vacancies on the web portal of vacancies "New Public Service" } \\
- & \text { (career.gov.ua) }\end{array}$ \\
\hline
\end{tabular}

2.1. The State Employment Service (SES) is a central body of executive power pursuing the state policy on employment and labor migration, including free offer of intermediary services on search of suitable jobs and staff selection. According to the Law of Ukraine "On Employment of the Population", the SES functions include analyses of data on labor force demand and supply, interactions with employers on issues of determining current and future needs in labor force, professional training of the population and staffing of free jobs. Employers are obliged to report SES the data on labor force demand (vacancies) and expected massive dismissals of employees due to organizational change in business operation and staffing. To carry out these and other assignments, SES operates the Single Information and Analytical System containing database on vacancies built on the information supplied by employers and business entities providing intermediary recruitment services [17].

However, according to employers, registered unemployed persons tend to seek for unemployment benefits rather than real jobs. Although such distrust of employers more often originates from prejudices than their own negative experiences, they are not so willing to supply SES with information on available vacancies [12]. The overall observance of the law on labor and employment in Ukraine is too low, especially because failure to supply data on vacancies does not entail financial sanctions. Also, employers may be discouraged by a very rigid format for data reporting, which, inter alia, requires that a vacancy be named according to the Classification of Professions and an exact salary size be indicated for each vacancy. Incomplete coverage is the main problem of SES data.

2.2. The Pension Fund of Ukraine (PFU) operates a high-capacity database of individual data on insured persons and insurers (i. e. the ones who pay contributions: enterprises, physical persons - entrepreneurs and others), accumulating data since the end of 1990s. Now $\mathrm{PFU}$ is installing a new service, "Electronic Employment Record Book", which will also contain records from paper employment record books over the period prior to the introduction of individual records of persons covered by pension insurance [18]. These data offer a unique base for analyses of employment biographies, carrier trajectories and logics of movement from one job to another. The main problem of this source is that it is completely close and inaccessible for statistical or research purposes.

2.3. The National Agency on Public Service (NAPS) is a source containing interdepartmental, but nevertheless niche, information on a narrow segment of the labor market. NAPS publishes reports on the number of public officials and vacancies in the public service, and operates the database of open vacancies on the web portal of vacancies "New Public Service" career.gov.ua.

Governmental monitorings. Monitoring and assessment are important components of effective management. But the monitoring practice in Ukraine is still dominated by extensive ways: while the number of monitorings is increasing, their effectiveness is too limited. Thus, the Ministry of Economy of Ukraine, which has been recently responsible for setting up employment policy, conducts several monitorings, but issues of labor market demand are practically overlooked in them. The Monitoring of government investment projects implementation, based on financial indicators, does not contain a mention of jobs that are already created or will be created by these projects [19]. The Monitoring of management effectiveness in the entities with public ownership contains data on the average recorded number of staff personnel, the average monthly wage and the wage arrears [20]. As subject to assessment is not an actual figure compared with the benchmark or average level, but only the vector of change, a positive or satisfactory estimate can be got by an enterprise with the wage level slightly exceeding statutory minimum wage.

It was in 2013 that the Ukrainian Ministry of Social Policy attempted to launch the monitoring of new job creation [21]. It was expected that it would rely on the system of recording administrative data (PFU in particular) on job placements of persons in newly created jobs and dismissals of persons from jobs due to the change in organization and staffing. The following analytical dimensions were proposed: wage range (as ratio to statutory minimum wage); organizational and legal form (enterprise - legal entity, physical person - 
entrepreneur, autonomous professional work); economic activity; region. Although the technique has been approved, results of the monitoring have never been published.

It was since February 2017 that PFU has published a monthly Information Sheet on the efforts to identify signs of use of undocumented workers and violations of labor legislation. The Sheet contains data on the dynamics of the number of insured persons with highlighting some categories (physical persons - entrepreneurs; employees; persons who worked part-time; persons who performed works by civil contracts; persons with disabilities), and on the wage range [22]. According to its purpose, the Sheet informs on some fiscal-organizational characteristics of insured persons, but tells nothing about restructuring of jobs across economic sectors.

Alternative sources. Examples of alternative sources providing information on labor market demand are given in Table 3 (developed by the author using data from the abovementioned websites)

Table 3

Examples of alternative data sources providing information on number and structure of jobs

\begin{tabular}{|l|l|}
\hline \multicolumn{1}{|c|}{ Source } & \multicolumn{1}{c|}{ Indicators/resources } \\
\hline 3.1. Independent analytics & $\begin{array}{l}\text { Publications of independent analytical centers: } \\
\text { - Institute of Economic Studies and Political Consultations, http://www.ier. } \\
\text { com.ua/ua/areas_of_research/fiscal_social_policy } \\
\text { - Kyiv School of Economics, https://kse.ua/ua/ } \\
\text { doslidzhennya/\#policyResearch } \\
\text { - Ukrainian Center of Social Reforms, } \\
\text { https://ucsr.kiev.ua/ua/publications and others }\end{array}$ \\
\hline $\begin{array}{l}\text { 3.2. Marketing studies, analytics } \\
\text { and online database of vacancies }\end{array}$ & $\begin{array}{l}\text { Websites of recruitment companies: } \\
\text { - Work.ua, https://www.work.ua/ } \\
\text { - robota.ua, https://rabota.ua/ } \\
\text { - HeadHunter, https://grc.ua/ and others }\end{array}$ \\
\hline $\begin{array}{l}\text { 3.3. Noncommercial niche sources } \\
\text { of various sectors }\end{array}$ & $\begin{array}{l}\text { Industry/sectoral websites with information on currently open positions, } \\
\text { such as search for volunteers for public organizations: } \\
\text { - Prostir.Ua, https://www.prostir.ua/ } \\
\text { - Webportal HURT, https://gurt.org.ua/ and others }\end{array}$ \\
\hline
\end{tabular}

The most informative alternative sources and online databases are specialized job search websites. To work with them, researchers must have IT skills and competencies of how to structure information and work with text data. The largest problem of this source is an arbitrary manner of information presentation, absence of clear criteria and requirements, large scopes of unverified information, incompleteness of information presentation and occurrences of not entirely truthful information. Thus, very often owners of vacancies do not indicate even an estimated wage size or manipulate with information, in order to lure inexperienced job seekers. Vacancy descriptions can often hide outsourcing or other form of unsecure employment (such as fictitious assignment of the status of physical person - entrepreneur) or contain discriminatory features (that more often occur in form of age or gender specifications). But combining of data from job search websites with the online database of SES can provide a broader range of vacancies for the assessment of scopes and structure of labor market demand.

Conclusions and recommendations. The statistical assessment of labor market demand requires a complex mix of information from various sources that give a notion of the total scopes and structural characteristics of jobs. This assessment can be based on traditional official sources (especially Labor Force Survey) supplemented by verified information from alternative sources. Instead of being focused on abstract macroprospects, assessments and analyses of labor market demand should aim to identify vectors and opportunities for development on a job place. Further studies in the field require elaboration of a methodological framework for harmonization of data from various sources, with special emphasis on the quality of information about open vacancies.

\section{References}

1. Human Development Report 2015: Work for Human Development (2015). United Nations Development Programme (UNDP). New York. Retrieved from http://hdr.undp.org/en/content/human-developmentreport-2015

2. Handbook on Measuring Quality of Employment: A Statistical Framework. (2015). ECE/CES/40. New York and Geneva: United Nations Economic Commission for Europe. Retrieved from https://unece.org/fileadmin/ DAM/stats/publications/2015/ECE_CES_40.pdf

3. Promoting employment and decent work in development cooperation. (2018; 2021). (Vols. 1, 2). Brussels, Luxembourg: EU Directorate-General for International Cooperation and Development. European Commission. Vol. 1: Concepts and foundations. 2018. 90 p. Retrieved from https://op.europa.eu/en/publication-detail/-/ publication/e3f73ec1-437b-11e8-a9f4-01aa75ed71a1/language-en; Vol. 2: Practical guidance for designing 
employment-focused interventions. 2021. 240 p. Retrieved from https://op.europa.eu/en/publication-detail/-/ publication/ccdf1eee-8d1b-11eb-b85c-01aa75ed71a1/language-en

4. Mykhailyshyna, D., Kobernik, O., \& Soltysyak, R. (2019). Yak zbilshyty zainiatist zhinok $i$ chomu tse vazhlyvo dlia ekonomiky? [How to increase women's employment and why is it important for the economy?]. Kyiv: Center for Economic Strategy. Retrieved from https://drive.google.com/file/d/1fE8T45rOWBYXxGZiGS13CPF0ItGGYZ-/view [in Ukrainian].

5. Tkalich, O. (2016). Pratsevlashtuvannia liudei iz invalidnistiu v Ukraini: formalnist i realii [Employment of people with disabilities in Ukraine: formality and realities]. Spilne - Common, 26.09.2016. Retrieved from https:// commons.com.ua/ru/pratsevlashtuvannya-lyudej-iz-invalidnistyu-v-ukrayini-formalnist-i-realiyi/ [in Ukrainian].

6. Del Carpio, X., Kupets, O., Muller, N., \& Olefir, A. (2017). Skills for a Modern Ukraine. Directions in Development - Human Development. Washington, DC: World Bank. Retrieved from https://openknowledge. worldbank.org/handle/10986/25741

7. Ofitsiinyi vebsait Derzhavnoi sluzhby statystyky Ukrainy [Official website of the State Statistics Service of Ukraine]. теrere.ukrstat.gov.ua. Retrieved from http://www.ukrstat.gov.ua/ [in Ukrainian].

8. Libanova, E., Tsymbal, O., Yarosh, O., \& Lisohor, L. (2016). Perekhid na rynok pratsi molodi Ukrainy: rezultaty mizhnarodnoho doslidzhennia "School-to-work transition surveys" v Ukraini u 2013 ta 2015 rokakh [Transition to the youth labor market of Ukraine: results of the international study "School-to-work transition surveys" in Ukraine in 2013 and 2015]. Geneva: International Labor Office. Retrieved from https://www.lo.org/ wcmsp5/groups/public/---ed_emp/documents/publication/wcms_536293.pdf [in Ukrainian].

9. Robocha syla Ukrainy. 2019: stat. zb. [Labor force of Ukraine. 2019: Statistical Yearbook]. (2020). wwro.ukrstat.gov.ua. Retrieved from http://www.ukrstat.gov.ua/druk/publicat/kat_u/2020/zb/07/ zb_r_s_2019.pdf [in Ukrainian].

10. Anonimni mikrodani za pokaznykamy shchodo robochoi syly ta yikh kharakterystykamy [Anonymous microdata on labor indicators and their characteristics]. (2018, 2019). wrewe.ukrstat.gov.ua. Retrieved from http:// www.ukrstat.gov.ua/operativ/micro_dani/menu/pr_htm [in Ukrainian].

11. Rukh kadriv [Staff movement]. (2017-2021). wrere.ukrstat.gov.ua. Retrieved from http://www.ukrstat. gov.ua/operativ/operativ2017/gdn/rkd/rkd_ek/rkd_ek_u.htm [in Ukrainian].

12. Nezhyvenko, O. (2020). Kompleksnyi analiz rehionalnoho rynku pratsi ta diialnosti Derzhavnoi sluzhby zainiatosti u Zaporizkii oblasti [Comprehensive analysis of the regional labor market and the activities of the State Employment Service in the Zaporozhye region]. wrero.ua.undp.org. Retrieved from https://www.ua.undp. org/content/ukraine/uk/home/library/recovery-and-peacebuilding/labour-market-state-employment-serviceactivity-Zaporizhzhia-Oblast.html [in Ukrainian]

13. Ochikuvannia pidpryiemstv shchodo perspektyv rozvytku yikh dilovoi aktyvnosti. [Expectations of enterprises regarding the prospects for the development of their business activity]. (2013-2021). wrere.ukrstat.gov.ua. Retrieved from http://www.ukrstat.gov.ua/operativ/menu/menu_u/tda.htm [in Ukrainian].

14. Analitychna ta statystychna informatsiya [Analytical and statistical information]. (2021). wrere.dcz.gov.ua. Retrieved from https://www.dcz.gov.ua/storinka/analityka-ta-statystyka [in Ukrainian].

15. Vidomosti pro trudovu diialnist [Information on employment]. portal.pfu.gov.ua. Retrieved April 15, 2021 from https://portal.pfu.gov.ua/sidebar/Templates/InfoTK [in Ukrainian].

16. Statystychni dani pro kilkisnyi sklad derzhavnykh sluzhbovtsiv u orhanakh derzhavnoi vlady [Statistical data on the number of civil servants in public authorities]. (2019-2021). nads.gov.ua. Retrieved from https://nads. gov.ua/diyalnist/kilkisnij-sklad-derzhavih-sluzhbovciv/kilkisnij-sklad-derzhanih-sluzhbovciv [in Ukrainian].

17. Pro zainiatist naselennia: Zakon Ukrainy vid 05.07.2012 r. № 5067-VI, stanom na 23.04.2021 r. [On Employment. Law of Ukraine of July 05, 2012 No 5067-VI as of April 23, 2021]. zakon.rada.gov.ua. Retrieved from https://zakon.rada.gov.ua/laws/show/5067-17\#Text [in Ukrainian].

18. Pro zaprovadzhennia obliku trudovoi diialnosti pratsivnyka, fizychnoi osoby - pidpryiemtsia, fizychnoi osoby, yaka zabezpechuie sebe robotoiu samostiino, v elektronnii formi: Postanova Kabinetu Ministriv Ukrainy vid 27.11.2019 r. № 1084 [On the introduction of labor accounting of an employees, individual entrepreneurs, and self-employed persons, in electronic form. Resolution of the Cabinet of Ministers of Ukraine of November 27, 2019. No 1084]. zakon.rada.gov.ua. Retrieved from https://zakon.rada.gov.ua/laws/show/1084-2019-\%D0\%BF\#Text [in Ukrainian].

19. Monitorynh stanu vykonannia ta realizatsii derzhavnykh investytsiinykh proektiv [Monitoring the status of implementation and realization of state investment projects]. (2016-2020). wrerc.me.gov.ua. Retrieved from https://www.me.gov.ua/Documents/List?lang=uk-UA\&id=40253ac5-2a8c-447d-857d-1a34739d765a\&tag=Mon itoringStanuVikonanniaTaRealizatsiiDerzhavnikhInvestitsiinikhProe [in Ukrainian].

20. Monitorynh efektyvnosti upravlinnia obiektamy derzhavnoi vlasnosti [Monitoring the effectiveness of management of state property].(2013-2020). wrerc.me.gov.ua. Retrieved from https://www.me.gov.ua/Documents/ 
List?lang=uk-UA\&id=2e24db81-1b0d-4322-80ce-89e6d3c269e2\&tag=MonitoringEfektivnostiUpravlinniaObie ktamiDerzhavnoiVlasnosti [in Ukrainian].

21. Pro zatverdzhennia Metodyky monitorynhu stvorennia novykh robochykh mists: Nakaz Ministerstva sotsialnoi polityky Ukrainy vid 23.09.2013 r. № 611. [On approval of the Methodology for monitoring the creation of new jobs. Order of the Ministry of Social Policy of Ukraine of September 23, 2013 No 611]. zakon.rada.gov.ua. Retrieved from https://zakon.rada.gov.ua/laws/show/z1749-13\#n13 [in Ukrainian].

22. Informatsiinadovidkashchodoprovedenoi roboty povyiavlenniu oznak vykorystanniapratsineoformlenykh pratsivnykiv ta porushen zakonodavstva pro pratsiu [Information on the work carried out to identify signs of the use of undocumented workers and violations of labor legislation]. (2017-2021). wroro.pfu.gov.ua. Retrieved from https://www.pfu.gov.ua/poslugi/splachuyu-yesv/platezhi-ta-poryadok-yih-splati/detinizatsiya-zarobitnoyi-platyta-legalizatsiya-zajnyatosti/ [in Ukrainian].

\author{
Л. Г. Ткаченко, \\ кандидат економічних наук, старший науковий співробітник, \\ провідний науковий співробітник, \\ Інститут демографії та соціальних досліджень \\ імені М. В. Птухи НАН України, \\ E-mail: lidiia1tkachenko@gmail.com \\ ORCID https://orcid.org/0000-0002-6352-6398
}

\title{
Інформаційне забезпечення статистичної оцінки попиту на ринку праці України
}

Статистична оцінка попиту на ринку праці має спрямовуватися не стільки на кількісні, скільки на якісні характеристики робочих місць з позицій можливостей вибору та розвитку працівників. Така оцінка робочих місць потребує інформаційного та методичного забезпечення. Проведений огляд наявних інформаційних джерел про кількість і структуру робочих місць дає підгрунтя для побудови комплексної оцінки на основі державних статистичних спостережень, доповнених адміністративними даними й альтернативними джерелами щодо вакансій. Показано, що кожне джерело має свої переваги та недоліки. Сильними сторонами офіційних джерел є системний професійний підхід та єдині методичні підходи до збирання й обробки даних, регулярний характер, контроль якості даних і відповідальність. Однак ці джерела залишаються малодоступними для дослідницьких цілей, дані формуються за формальновідомчим підходом і публікуються в надто агрегованому вигляді. Альтернативні джерела, зокрема незалежні аналітичні й маркетингові дослідження, електронні бази вакансій, перебувають у відкритому доступі та містять детальні описи вільних робочих місць. Але ці дані неструктуровані, фрагментарні та потребують обережного застосування через високу імовірність системних зміщень, викликаних широким застосуванням маркетингових стратегій.

В основу комплексної оцінки попиту на ринку праці мають бути закладені результати обстеження робочої сили, які дають можливість одночасного структурування показників за соціально-демографічними ознаками респондентів та організаційно-економічними характеристиками виробничих одиниць. Дані цього обстеження мають бути доповнені даними обстежень підприємств з питань статистики праці, умов праці та ділової активності, деперсоніфікованими даними реєстрів Пенсійного фонду України, а також даними про вакансії, які є в базах даних Державної служби зайнятості та приватних посередників 3 працевлаштування.

Ключові слова: ринок пращі, попит та пропозиція на ринку праці, робоча сила, вакансії, статистичні спостереження, адміністративні дані, моніторинг.

Bibliographic description for quoting:

Tkachenko, L. H. (2021). Informatsiine zabezpechennia statystychnoi otsinky popytu na rynku pratsi Ukrainy [Information Support for the Statistical Assessment of Labor Market Demand in Ukraine]. Statystyka Ukrainy - Statistics of Ukraine, 2, 101-108. Doi: 10.31767/su.2(93)2021.02.10

Бібліографічний опис для цитування:

Ткаченко Л. Г. Інформаційне забезпечення статистичної оцінки попиту на ринку праці України (публікується англійською мовою). Статистика Украйни. 2021. №2. С. 101-108. Doi: $10.31767 /$ su.2(93)2021.02.10 